\title{
ANALISIS KINERJA DINAS SOSIAL KOTA PADANG DALAM PENANGGULANGAN BENCANA DI KOTA PADANG (SUATU STUDI MANAJEMEN KEBENCANAAN)
}

\author{
Arief Ivana Putra \\ Jurusan Ilmu Administrasi Negara \\ ifanahrif@gmail.com \\ Zikri Alhadi, S.IP, MA \\ Jurusan Ilmu Administrasi Negara \\ ianunpzikri@yahoo.co.id
}

\begin{abstract}
The research purpose to examine how the performance of the Office of Social Services for disaster management, and the steps taken by the Office of Social Services in disaster management in the City of Padang. This research was carried out at government institutions in the city of Padang, namely the Social Service Office at the Padang city. The research type is descriptive qualitative, file sourced from primary file and secondary file. This file is obtained by interview techniques and documentation. The result of the study indicate that performance of Social Service towards disaster management in Padang City was quite good, but the performance of the Social Service was not optimal. This can be seen from the performance of the Office of Social Affairs which is still experiencing obstacles in terms of facilities, lack of available funds and lack of experience in information technology workers.
\end{abstract}

Keywords: performance, disaster management 


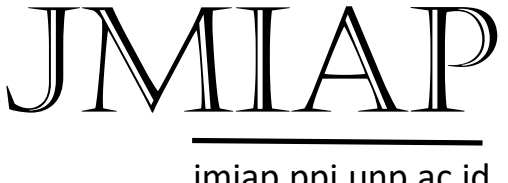

jmiap.ppj.unp.ac.id

\section{Pendahuluan}

Bencana merupakan suatu pergolakan alam yang tidak dapat dihindari oleh siapapun yang memiliki dampak fisik, ekonomi maupun psikologis. Dampak tersebut sangat dirasakan oleh para korban bencana yang bermukim di lokasi kejadian bencana, dimana mereka harus siap siaga setiap waktu. Bencana banjir, gunung meletus, tanah longsor, gempa bumi, tsunami dan puting beliung merupakan bencana yang sering melanda daerah Indonesia. Menurut catatan Direktorat Vulkanologi dan Mitigasi Bencana Geologi (DVMBG) Departemen Energi dan Sumber Daya Mineral, mencatat bahwa terdapat 28 wilayah rawan gempa tsunami di Indonesia. Penanggulangan bencana merupakan sebuah issue dan gerakan global dalam menangani dampak yang ditimbulkan oleh bencana tersebut. Di setiap daerah harus memiliki karakteristik yang khas dalam mempersiapkan perencanaan tersendiri dalam menanggulangi bencana karena wilayah Indonesia sebagian besar berada dari pertemuan dua lempeng dunia, yaitu patahan bumi lempeng Autralia dan Asia (Eurasia), hal ini mengakibatkan Indonesia selalu terancam akan becana alam.

Penanggulangan bencana yang komprehensif (menyeluruh) di Indonesia dibuktikan dengan adanya Undang Undang Nomor 27 tahun 2007 mengenai Penanggulangan Bencana serta dikuatkan oleh Peraturan Pemerintah Nomor 21 tahun 2008 mengenai Penyelenggaraan Penanggulangan Bencana. Dijelaskan bahwa dalam (Undang Undang tentang penanggulangan bencana, 2007) pada Pasal 1 yaitu Bencana merupakan peristiwa atau rangkaian peristiwa yang mengancam dan mengganggu kehidupan dan penghidupan masyarakat yang disebabkan, baik oleh faktor alam dan/atau faktor non alam maupun faktor manusia, kerusakan lingkungan, kerugian harta benda, dan dampak psikologis.
Sumatera Barat berada pada dua posisi yang bisa mengancam terjadinya bencana besar yaitu, berada di antara 2 retakan, retakan Mentawai diantara Pesisir Barat dengan Kepulauan Mentawai serta disepanjang Bukit Barisan yang biasa disebut retakan Sumatera. Sejarah Sumatera Barat yang dilanda gempa besar pada tahun 2009, membuktikan bahwa Sumatera Barat merupakan daerah rawan bencana. Tercatat bahwa Kota Padang memiliki korban terbanyak dibandingkan dengan daerah Sumatera barat lainnya, tercatat pada saat gempa bumi tahun 2009 terdapat 327 korban jiwa di Kota Padang, sedangkan pada daerah lainnya hanya berkisar puluhan korban jiwa kecuali pada Kabupaten Padang Pariaman yaitu terdapat sebanyak 292 korban jiwa.

Pemerintah, masyarakat dan lembaga usaha ialah aktor penting dalam penanggulangan bencana, dimana berarti penanggulangan bencana bukan hanya saja tanggungjawab Pemerintah, namun seluruh elemen masyarakat ikut andil dalam hal ini. Serangkaian upaya yang dilakukan seperti penetapan kebijakan pembangunan yang berisiko timbulnya bencana, beragam kegiatan pencegahan bencana, tanggap darurat dan rehabilitasi merupakan penyelenggaraan penanggulangan bencana. Beberapa aktifitas pengurangan risiko bencana tentunya memerlukan koordinasi antara berbagai instansi seperti perguruan tinggi, LSM, dan BPBD yang sebagai koordinator pelaksananya.

Menurut narasumber Patra Rina Dewi, S.Si, M.Sc (Konsultan mitra pengurangan resiko bencana BNPB, BPD dan UNDP), Dalam perda, RAD, Tujuan dari penanggulangan bencana di indonesia berdasarkan dengan UU PB masih dalam proggres (on the way) dan bisa dibilang belum tercapai. Di global ada kerangka sendai, kalau di Indonesia seharusnya punya platform, di nasional sendiri kota padang memang punya Renas PB (rencana nasional penanggulangan bencana) dan itu 


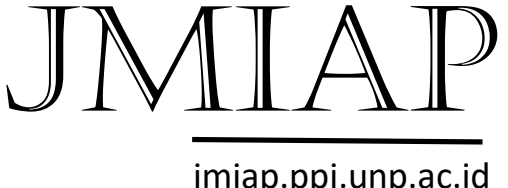

jmiap.ppj.unp.ac.id memang harus mengacu kepada kerangka sendai. Karena setiap tahun akan dilaporkan ke National Global Platform for disaster risk reduction dan seluruh anggota $\mathrm{PBB}$ yang meratifikasi kerangka hiyogo wajib melaporkan.

Patra Rina Dewi, S.Si, M.Sc (Konsultan mitra pengurangan resiko bencana BNPB, BPD dan UNDP) menambahkan, Hampir seluruhnya belum tercapai. Kalau Minset kota padang sudah bergerser ke pra bencana, mitigasi dan kesiapsiagaan sudah mulai bergeser. Tapi tak bisa dikatakan bergeser seluruhnya, karena masih ada daerah-daerah di Indonesia yang belum fokus, belum mengarusutamakanpengurangan resiko kebencanaan pada saat pra bencana, jadi masih tanggap darurat bencana (response). Kota padang sudah punya rencana pananggulangan bencana daerah (RPB). Setiap daerah sudah punya RPB walaupun belum semua daerah yang menjadikan RPB itu sebagai kerangka kebijakan. SeharusnyaRPB di perda kan, dan di kota padang sudah menjadi Perda RPB. RPB turunannya $\mathrm{RAD}$ untuk pengurangan resiko bencana dari RAD masing-masing OPD menyusun renstra kemudian dari renstra itu muncul nanti namanya renja. Dari rencana kerja itu sudah bisa dilihat indikatornya seperti apa, akan tetapi tidak ada yang mengevaluasi.Kalau kota padang sudah lebih maju dalam penanggulangan bencana. Karena payung hukum sudah ada. Perda penanggulangan bencananya ada, perwako protap tanggap daruratnya ada. Padang itu sudah termasuk maju karena kelengkapan kebijakan sudah ada. Yang belum ada itu rencana kontijensi yang belum diperwako kan. Yang sudah itu provinsi sudah ada pergubnya dan bahkan sudah dua kali di perbaharui. Namun untuk dukungan legislatif ke pengurangan risiko bencana masih lemah.

Patra Rina Dewi, S.Si, M.Sc (Konsultan mitra pengurangan resiko bencana BNPB, BPD dan UNDP) menegaskan, Renstra dan Renja pembagian fungsi masing-masing OPD sudah digariskan, tapi tidak ada peraturan yang mengiikat mereka untuk benar-benar melaksanakan kinerja yang baik, karena kita tidak tau kalau misalnya ada penilaian OPD, bagaimana penilaian kinerja performa sebuah instansi. apakah pengurangan resiko bencana ini sudah termasuk dalam penilaian (program yang dibuat) sehingga kinerja dari sebuah instansi termasuk indikator penilaian untuk menilai kinerja.

Patra Rina Dewi, S.Si, M.Sc (Konsultan mitra pengurangan resiko bencana BNPB, BPD dan UNDP) menjelaskan bahwa, Fungsi Dinas Sosial bekerja untuk memberikan bantuan dapur umum/logistik. Dinas sosial mempunyai TAGANA tapi di fungsikan pada saat tanggap darurat. Itu salah satu bukti bahwa minset masih setengah bergeser ke tanggap darurat.

Dinas Sosial perlu memiliki Renja \& Restra. Martias (Kepala Bidang LINJAMSOS) menjelaskan bahwa restra \& renja Dinas sosial masih perlu dievaluasi ulang karena tidak sesuai dengan SOP Dinas Sosial khususnya bidang Linjamsos. Secara umum dinas sosial dalam penanggulangan bencana berperan untuk memberikan bantuan logistik/dapur umum. Karena tupoksinya Dinas Sosial dalam penanggulangan bencana adalah merencanakandan melaksanakan penyediaan kebutuhan logistik bencana. Dinas Sosial akan memberikan bantuan terhadap mayarakat yang tertimpa bencana, bantuan yang diberikan dinas sosial juga bisa berupa bantuan fisik, akan tetapi bantuan fisik yang diberikan terbatas karena berpatokan kepada anggaran yang didapat dinas sosial dari APBN dan APBD, sehingga terpaksa dinas sosial menggunakan dana seadanya dan bekerja sama dengan instansi terkait dalam penanggulangan bencana. 


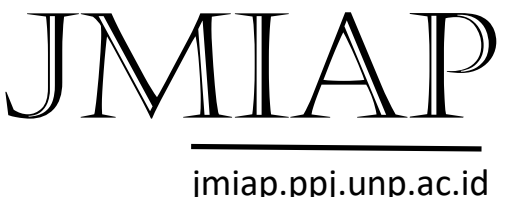

jmiap.ppj.unp.ac.id
Dalam memenuhi bahan yang berkaitan dengan bantuan sosial dan penanggulangan bencana, Dinas Sosial dibantu Tagana dalam mengumpulkan bahan dan data yang berkaitan dengan bencana, tentunya ini mempengaruhi kinerja Dinas Sosial tersebut. Selain itu, dinas sosial juga berperan dalam membina taruna saga bencana bersama tim terpadu, namun hal ini tidak berjalan sebagaimana mestinya dikarenakan tidak terstrukturnya kinerja dinas Sosial.

Dari beragam uraian diatas, dalam mewujudkan optimalisasi penanggulangan kesiapsiagaan bencana, diperlukan kinerja yang tepat dan baik dari dinas sosial. Hal ini dikarenakan dinas sosial merupakan pihak yang berkerja untuk pemenuhan logistik/dapur umum dalam penanggulangan bencana, sesuai dengan peraturan Walikota Padang Nomor 28 Tahun 2015, Pasal 15 angka 3 yang menjelaskan mengenai penjabaran fungsi dan tugas pokok Dinas Sosial. Di kota Padang sendiri, Pemerintah daerah bersama Dinas Sosial juga memiliki peran penting dalam upaya mengurangi resiko bencana. namun kurangnya SDM yang dimiliki Dinas sosial dalam melakukan kajian dan analisa resiko bencana, sehingga potensi bahkan bencana itupun sering terjadi dan selalu menjadi ancaman bagi masyarakat. Martias (Kepala Bidang LINJAMSOS) menuturkan bahwa, dalam bidang penanggulangan bencana Dinas sosial sendiri hanya memiliki 5 orang SDM, sehingga berpengaruh terhadap pelaksanaan evaluasi dan monitoring bantuan sosial bencana alam, kesiapsiagaan, sarana dan prasarana pun tidak berjalan dengan baik.

Tak hanya itu masalah yang ditemukan dalam kinerja Dinas Sosial, Lambatnya koordinasi Dinas Sosial dengan camat/lurah, RW dan RT tentang apa yang dibutuhkan korban saat terjadinya bencana merupakan kendala dalam pelaksanaan tugas. Tidak adanya pendataan langsung dari Dinas Sosial terkait korban dari bencana yang terjadi. Sedangkan komunikasi Dinas Sosial terhadap respon dari kebutuhan korban pasca bencana, Dinas Sosial hanya menunggu instruksi dari lining sektor penanggulangan bencana untuk pemenuhan bufeastock. Untuk pemenuhan Bufeastock/logistik/dapur umum persediaan yang ada di gudang milik dinas sosial hanya terdapat berupa peralatan seperti, tenda, alat dapur dll, sementara sandang \& pangan tidak tersedia di gudang. Hal tersebut dapat memperlambat kerja dinas sosial dalam memberikan bantuan, karena dinas sosial harus membeli seluruh kebutuhan perlengkapan terlebih dahulu. Tidak adanya Edukasi terhadap Peningkatan kemampuan dan kepedulian SDM di Dinas Sosial yang beperan untuk penanggulangan bencana.

Dalam kinerja tentunya perlu ada sebuah evaluasi atau monitoring kerja supaya kinerja sebuah organisasi/instasi bisa dikatakan berhasil, dinas sosial khususnya bidang Linjamsos hanya melaksanakan monitoring ketika pasca bencana saja sementara monitoring kerja perlu dilakukan secara berskala, supaya bisa mengetahui apasaja kekurangan dalam sebuah kerja.

Yang menjadi rumusan masalah berdasarkan latar belakang diatas dalam penelitian ini yaitu:

1) Bagaimana kinerja Dinas Sosial dalam penanggulangan bencana di Kota Padang?

2) Apasaja faktor analisis SWOT pada kinerja Dinas Sosial dalam penanggulangan bencana?

\section{Tinjauan Kepustakaan \\ Konsep Kinerja}

Kinerja merupakan ukuran sebuah hasil kerja. (Wibowo, 2008) menuturkan bahwa Kinerja berasal dari pengertian performance, yaitu sebagai hasil kerja atau prestasi Indonesia. Sedangkan menurut (Pasolong, 2010) mengatakan bahwa 


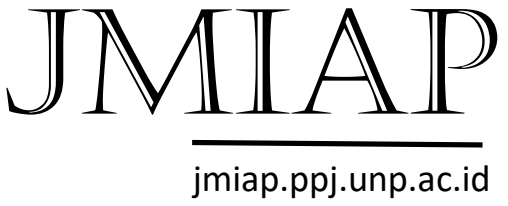

kinerja ialah hasil kerja perseorangan dalam suatu organisasi.

\section{Konsep Penanggulangan Bencana}

Bencana merupakan segala sesuatu hal yang dapat menimbulkan kerusakan. Menurut Arie Priambodo, dalam (Alhadi, 2014) menuturkan bahwa bencana ialah suatu kejadian alam, perbuatan manusia, atau perpaduan antara keduanya yang terjadi secara tiba-tiba sehingga menimbulkan dampak negatif yang dahsyat bagi kelansungan kehidupan.

Faktor penyebab terjadinya bencana ada 3 faktor,

1. Faktor alam (natural disaster) terjadi secara alami, biasanya disebabkan oleh fenomena alam.

2. Faktor non alam (non natural disaster) disebabkan bukan karena kejadian alam maupun ulah tangan manusia.

3. Faktor sosial manusia, biasanya terjadi karena kelalaian manusia seperti erosi yang terjadi akibat penebangan hutan sembarangan maupun konflik.

Penanggulangan bencana ialah sebuah proses terpadu nan dinamis serta berkelanjutan guna mengurangi resiko terjadinya bencana berupa rangkaian kegiatan yang meliputi pencegahan, mitigasi, kesiapsiagaan, tanggap darurat, rehabilitasi dan pembangunan kembali.

Pasal 3 dalam (Undang Undang tentang penanggulangan bencana, 2007) menjelaskan bahwa penanggulangan bencana didasarkan pada prinsip kemanusiaan, keadilan, kesamaan kedudukan dalam hukum dan pemerintahan, keseimbangan dan keselarasan, ketertiban dan kepastian hukum, kebersamaan, kelestarian lingkungan hidup, ilmu pengetahuan dan teknologi.

\section{Konsep Analisis SWOT}

Menurut (Rangkuti, 2006) Analisis SWOT merupakan teknik identifikasi
Email : jianfis.unp@gmail.com Vol.2 No.1 Maret 2019

secara sistematis berbagai faktor guna untuk melakukan evaluasi terhadap sesuatu. Strength (kekuatan), Weakness (kelemahan), Opportunities(peluang), dan Threat(ancaman), ke 4 istilah ini merupakan singkatan dari SWOT.

Analisis SWOT disebut juga berdasarkan logika yang memaksimalkan kekuatan (strength) dan peluang (opportunities), akan tetapi secara bersamaan juga dapat meminimalkan kelemahan (weakness) dan ancaman (threat). Hal ini biasa disebut dengan analisis situasi. Berikut merupakan tabel matriks SWOT.

Tabel Matriks SWOT

\begin{tabular}{|l|l|l|}
\hline & Kekuatan & $\begin{array}{l}\text { Kelemaha } \\
\mathrm{n}\end{array}$ \\
\hline $\begin{array}{l}\text { Peluang } \\
\text { (Opportunitie } \\
\text { s-O) }\end{array}$ & $\begin{array}{l}\text { (Strength } \\
\text { s-S) }\end{array}$ & $\begin{array}{l}\text { (Weaknes } \\
\text { s-W) }\end{array}$ \\
\hline $\begin{array}{l}\text { Ancaman } \\
\text { (Threats-T) }\end{array}$ & $\begin{array}{l}\text { Strategi } \\
\text { ST }\end{array}$ & $\begin{array}{l}\text { Strategi } \\
\text { WT }\end{array}$ \\
\hline
\end{tabular}

Sumber: Freddy Rangkuti

Menurut tabel, diketahui bahwa so ialah memanfaatkan seluruh kekuatan dengan memperhitungkan peluang, WO memanfaatkan kelemahan dengan memperhatikan peluang, ST ialah memanfaatkan kekuatan dengan memperhatikan ancaman, danWT memanfaatkan kelemahan dengan memperhatikan ancaman.

\section{Metode Penelitian}

Penelitian ini menggunakan metode deskriptif dengan pendekatan kualitatif. Penelitian ini berlokasi di Dinas Sosial Kota Padang. Teknik analisis data yang digunakan yaitu teknik wawancara dan studi dokumentasi. Penelitian ini menggunakan uji keabsahan data dengan teknik triangulasi. Informan penelitiannya menggunakan purposive sampling.

\section{Hasil dan Pembahasan}

Berdasarkan hasil temuan dalam penelitian dapat dilihat bahwa kinerja Dinas 


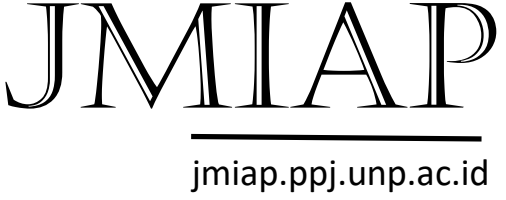

Sosial Kota Padang berdasarkan indikator kinerja menurut Gomez (Ellyta Yullyanti, 2009) terdapat beberapa penilaian kinerja yaitu:

a. Kualitas kerja

Kualitas kerja Dinas Sosial Kota Padang, dapat dikatakan sudah optimal. Dibuktikan dengan adanya Dinas Sosial Kota Padang menerima beberapa penghargaan dari Kementrian Sosial. Hal tersebut dibuktikan dengan dijadikannya Dinas Sosial Kota Padang sebagai acuan studi banding bagi dinas sosial lainnya di Sumatera Barat.

b. Kuantitas kerja

Kuantitas kerja Dinas Sosial Kota Padang sudah cepat tanggap dalam penanggulangan bencana. Hal ini dibuktikan dengan adanya data rekapan bencana alam tahunan yang terjadi di kota padang.

c. Pengetahuan Pekerjaan

Pengetahuan pekerjaan pegawai Dinas Sosial Kota Padang terhadap penanggulangan bencana sudah cukup baik, hanya saja dari segi pemahaman IT (ilmu teknologi) dinas sosial masih perlu perkembangan lagi.

d. Kerjasama

Kerjasama antar pegawai Dinas Sosial Kota Padang memiliki loyalitas kerja yang tinggi. Hal tersebut dibuktikan dari kerjasama pegawai dinas sosial dalam menangani kasus seorang ibu yang terlantar untuk dikembalikan kekampung halamannya dengan memberikan bantuan berupa uang hasil sumbangan dari seluruh pegawai dinas sosial.

e. Inisiatif
Email : jianfis.unp@gmail.com Vol.2 No.1 Maret 2019

Inisiatif kinerja dinas sosial cukup baik. Hal tersebut dibuktikan dengan adanya relasi antara dinas sosial dengan para donatur maupun CSR yang mau berkerjasama untuk membantu dinas sosial dalam pendanaan guna pemenuhan kebutuhan bufealstock.

f. Ketergantungan

Dinas sosial bergantung pada kebutuhan transportasi demi memperlancar kinerja dalam penanggulangan bencana di daerah yang sulit di jangkau. Dinas sosial juga sangat bergantung pada APBN dan APBD yang menganggarkan dana untuk kebutuhan dinas sosial dalam pelaksanaan kinerja.

\section{PENUTUP}

A. Kesimpulan

Dapat dilihat dari beberapa indikator kinerja Gomez (Ellyta Yullyanti, 2009):

1. Kualitas kerja dinas sosial dikatakan sudah baik, hal ini terlihat dari dijadikannya Dinas Sosial sebagai acuan studi banding bagi dinas sosial lainnya di Sumatera Barat. Dinas sosial juga memiliki rekan kerja dalam penanggulangan bencana, dalam hal lain disebut Tagana (taruna siaga bencana). Tagana sendiri memiliki anggota yang terdiri dari masyarakat (sukarelawan), tagana dilatih oleh dinas sosial dalam bidang kebencanaan guna membantu dinas sosial dalam penanggulangan bencana.

2. Kuantitas Kerja Dinas Sosial Kota Padang sudah cepat tanggap dalam penanggulangan bencana, meskipun pengetahuan pekerjaan Dinas Sosial dibidang IT masih perlu dikembangkan lagi karena dalam kinerja dinas sosial juga 


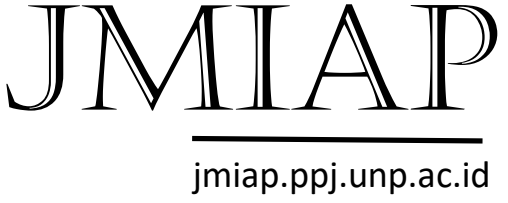

membutuhkan pegawai yang menguasai IT untuk membantu pekerjaan dinas sosial terkait pendataan dll.

3. Pengetahuan Pekerjaan pegawai Dinas Sosial Kota Padang terhadap penanggulangan bencana sudah cukup baik, bahkan dengan adanya kegiatan pelatihan yang setiap tahunnya dilakukan oleh Kementrian Sosial terhadap pegawai Dinas Sosial dan Tagana menjadikan pegawai dilingkup instansi tersebut menjadi terbiasa, hanya saja dari segi pemahaman IT (ilmu teknologi) dinas sosial masih perlu perkembangan lagi atau penambahan pegawai dalam bidang IT.

4. Kerjasama antar pegawai dinas sosial cukup tinngi. Karena dinas sosial sendiri terdiri dari orang orang yang berjiwa sosial. Pegawai dinas sosial, terutama bidang linjamsos terlihat sangat loyal dalam pekerjaan yang membantu masyarakat yang sesuai dengan tugas fungsi dinas sosial. Hal tersebut membuktikan bahwa kerjasama tim dibidang Linjamsos Dinas Sosial terjalin dengan baik.

5. Inisiatif kinerja dinas sosial cukup baik. Dinas sosial memiliki inisiatif dalam pelaksanaan tugasnya, hal tersebut terlihat ketika dinas sosial mengalami kekosongan khas (dana bantuan) mereka melakukan iuran perorangan untuk membeli bahan pokok dapur sebagai bantuan terhadap masyarakat yang mengalami bencana. Penulis beranggapan bahwa hal tersebut sangat jarang dilakukan oleh instansi - instansi lain demi kepuasan kerja dalam melayani
Email : jianfis.unp@gmail.com Vol.2 No.1 Maret 2019

masyarakat maka hal tersebut patut di apresiasi.

6. Ketergantungan, Dinas Sosial Kota Padang sangat bergantung pada APBN dan APBD meskipun dinas sosial juga berkerja sama dengan perusahaan/relasi/mitra kerja CSR maupun donatur yang bersedia membantu dalam terciptanya penanggulangan bencana yang cepat tanggap. Hal tersebut masih belum mencukupi dalam kebutuhan transportasi demi memperlancar kinerja dalam penanggulangan bencana di daerah yang sulit di jangkau ketika penanggulangan bencana dilaksanakan.

\section{B. Saran}

Saran yang peneliti rekomendasikan berdasarkan kesimpulan, yaitu sebagai berikut.

1. Meningkatkan SDM yang berkualitas guna mengenali dan memahami perkembangan IT (Ilmu Teknologi), hal ini mengingat banyak pegawai Dinas Sosial merupakan pegawai lama, sehingga banyak yang tidak melek teknologi.

2. Untuk lokasi kantor pusat Dinas Sosial kota Padang seharusnya berada pada satu titik kumpul dari setiap gedung/kantor yang memiliki kaitan dibidang dinas sosial. Seperti gudang yang beralamatkan di aia pacah, sementara kantornya berada di ujung gurun.

3. Dalam kinerja, Dinas Sosial seharusnya lebih sering melakukan monitoring dan evaluasi terhadap tantangan yang akan dihadapi Dinas Sosial kedepannya dalam proses/upaya penanggulangan bencana, serta menyusun planing baru yang mendukung dalam kinerja penanggulangan bencana di kota Padang. 


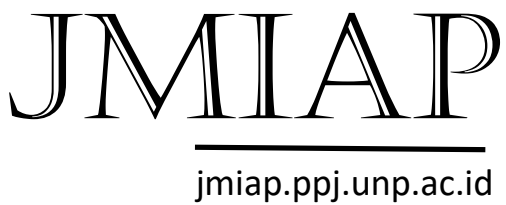

6. DAFTAR PUSTAKA

Alhadi, Z. (2014). Kesiapan Jalur Dan Lokasi Evakuasi Publik Menghadapi Resiko Bencan Gempa Dan Tsunami Di Kota Padang (Studi Manajemen Bencana), XIII, 35-38.

Ellyta Yullyanti. (2009). analisis proses rekrutmen dan seleksi pada kinerja pegawai. Jurnal Ilmu Administrasi Dan Organisasi, 16.
Pasolong, H. (2010). Teori Administrasi Publik. Bandung: Alfabet.

Rangkuti, F. (2006). Analisis SWOT Teknik Pembelah Kasus Bisnis. Jakarta: PT Gramedia Pustaka Umum.

Undang Undang penanggulangan bencana, Pub. L. No. 24 (2007).

Wibowo. (2008). manajemen kinerja. Jakarta: Rajawali Pers. 